\title{
Pendidikan Anak Usia Dini Berbasis Tauhid (Studi Kasus PAUD Ababil Kota Pangkalpinang)
}

\author{
Ria Astuti ${ }^{1}$, Erni Munastiwi² \\ 1IAIN Madura, Kota Pamekasan, Indonesia, Email: riaa370@gmail.com \\ 2UIN Sunan Kalijaga, Kota Yogyakarta, Indonesia, Email: \\ munastiwi_erni@yahoo.com
}

\begin{abstract}
ABSTRAK
Penelitian ini merupakan penelitian studi kasus dengan pendekatan kualitatif deskriptif yang dilakukan di PAUD Ababil Kota Pangkalpinang. Tujuan dari penelitian ini adalah (1) mendeskripsikan konsep pendidikan anak usia dini berbasis tauhid, (2) mendeskripsikan implementasi konsep pendidikan anak usia dini berbasis tauhid, serta (3) mendeskripsikan hasil dan dampak impementasi konsep pendidikan anak usia dini berbasis tauhid di PAUD Ababil Kota Pangkalpinang. Teknik pengumpulan data dari penelitian ini adalah dengan observasi, wawancara, dan dokumentasi. Hasil penelitian menunjukkan bahwa konsep pada pembelajaran tauhid yang diajarkan di PAUD Ababil ini merupakan pemahaman tentang Keesaan Allah SWT dengan memberikan pembiasaan-pembiasaan ibadah seperti sholat, do'a harian, hadits-hadits, surat pendek, dan kegiatan ikhsan lainnya. Pembelajaran tauhid sudah diajarkan dari usia 6 bulan sampai 6 tahun. Penyampaian materi pembelajaran tauhid yang dilakukan guru tergantung tingkatan umur dan kelasnya. Dampak dari implementasi pembelajaran tauhid ini adalah anak didik mampu melakukan praktek ibadah berdasarkan panduan ajaran Islam dalam kehidupan seharihari.

Kata Kunci: Pendidikan Anak Usia Dini, Tauhid
\end{abstract}

\begin{abstract}
This research is a case study with qualitative-descriptive approach in Ababil Playgroup, Pangkalpinang. It aims to describe these following points: (1) the concept of tauhid based early childhood education (2) the implementation of tauhid based early childhood education (3) the result and the impact of tauhid based early childhood education in Ababil Playgroup, Pangkalpinang. The data of this research is obtained from observation, interview and documentation. The result shows that the concept of tauhid based learning performed in Ababil playgroup consists of the understanding of the Oneness of Allah through creating habitation of worships such as performing prayers, reciting daily prayers, hadits, short Qur'anic surahs and other ihsan activities. It is applied to students ranging from 6 months to 6 years old. The tauhid curricula learning delivery depends on the age of students and the class they are in. The impact of this learning is the ability of students to practice daily worships based on Islamic guidance and teaching.
\end{abstract}

Keywords: Eearly Chilhood Education, Tauhid

Article history:

Received: 28-11-2018

Revised: 10-1-2019

Accepted: 14-1-2019 


\section{PENDAHULUAN}

Dewasa ini banyak anak-anak Bangsa Indonesia yang mengikuti arus globalisasi yang belum bisa diterima oleh rakyat Indonesia dengan positif sehingga membentuk karakter anak bangsa yang jauh dari nilai-nilai Islam dan ideologi Pancasila. Pergaulan bebas yang berujung pada free sex, narkoba, minum-minuman keras, video porno dan berbagai perilaku negatif lainnya yang dewasa ini menjangkit anak bangsa. Padahal, anak-anak dan remaja Indonesia adalah aset bangsa yang harus dibekali dengan karakter positif sejak dini agar bisa menjadi modal membangun negeri, bukan sebaliknya hanya menambah beban negara. Elizabeth B. Hurlocke dalam buku Suyadi dan Maulidya Ulfah (2012: 47), seorang tokoh Psikologi menyatakan bahwa:

"Kenakalan remaja bukanlah fenomena baru dari masa remaja melainkan suatu lanjutan dari pola perilaku asosiasi yang mulai pada masa kanak-kanak. Semenjak usia 2-3 tahun ada kemungkinan mengenali anak yang kelak menjadi remaja nakal."

Oleh karena itu, anak-anak

harus dibekali ilmu tentang tauhid sejak dini. Tauhid merupakan bagian dari akidah seorang muslim terhadap Allah SWT. Apabila tauhid seseorang benar, maka baik pula agamanya yang mana di dalam hal ini adalah agama Islam. Begitu juga sebaliknya. Apabila tauhidnya salah, maka pemahamannya terhadap ajaran Islam juga salah. Pendidikan tauhid harus menjadi prioritas utama dalam memberikan pendidikan kepada anak usia dini. Bagi seorang muslim, bertauhid merupakan pangkal sekaligus ujung (tujuan) dari seluruh kehidupannya. Artinya, seluruh aktivitas kehidupannya harus ada dan tetap dalam bingkai tauhid. Tauhid tidak hanya mengisi sisi kosong kesadarannya, melainkan selalu mengaliri ruang kesadarannya dalam waktu kapanpun dan dalam keadaan bagaimanapun (M. Hasbi, 2009: 3-4).

Hal ini sangat penting untuk mencegah pergaulan bebas di kemudian hari. Namun, penanaman nilai tauhid ini harus dilakukan secara berkesinambungan antara di rumah, lingkungan bermain dan sekolah. Untuk di rumah dan lingkungan bermain bisa dipantau oleh kedua orang tua bagaimana perkembangan tauhid anak. Adapun untuk di sekolah pendidikan 
dilakukan oleh guru. Karena tidak bisa dipungkiri bahwa guru dan sekolah memberikan pengaruh yang besar dalam penanaman nilai tauhid anak didik. Tanpa adanya penanaman nilai tauhid pada anak, maka anak akan tumbuh menjadi pribadi yang kurang berakhlak dan berkarakter. Untuk itu, pada karya ilmiah ini penulis akan membahas tentang "Pendidikan Tauhid Anak Usia Dini di PAUD Ababil" yang terletak di Kota Pangkalpinang Provinsi Bangka Belitung. Tujuan dari penulisan karya ilmiah ini adalah untuk mendeskripiskan konsep pembelajaran berbasis tauhid di PAUD Ababil, mendeskripiskan penerapan konsep pembelajaran berbasis tauhid di PAUD Ababil, dan mendeskripiskan implikasi penerapan konsep pembelajaran berbasis tauhid di PAUD Ababil.

\section{METODE}

Penelitian ini merupakan penelitian kualitatif deskriptif yang mendeskripsikan konsep pembelajaran berbasis tauhid di PAUD Ababil, penerapan konsep pembelajaran berbasis tauhid di PAUD Ababil, dan implikasi penerapan konsep pembelajaran berbasis tauhid di PAUD Ababil. Dalam penentuan subjek penelitian, peneliti menggunakan teknik purposive sampling dan snowball sampling. Subjek penelitian ini adalah Kepala Yayasan TK Ababil, Kepala Sekolah TK Ababil, guru kelas, perilaku peserta didik, dan orang tua. Metode yang digunakan untuk mengumpulkan data dalam penelitian ini adalah metode observasi, wawancara, serta dokumentasi. Dalam menganalisis data, peneliti menggunakan model Miles dan Huberman selama berada di lapangan. Aktivitas dalam analisis data meliputi data reduction, data display, dan conclusion drawing/ verification (Sugiyono, 2016: 338).

\section{HASIL PENELITIAN DAN PEMBAHASAN}

\section{A. Konsep Pendidikan Tauhid Anak Usia Dini}

Pembelajaran bagi anak usia dini di PAUD Ababil berbasis tauhid. Tauhid bukan sekedar mengenal dan mengerti bahwa pencipta alam semesta ini adalah Allah; bukan sekedar mengetahui bukti-bukti rasional tentang kebenaran wujud (keberadaan) Nya, dan wahdaniyah 
(keesaan) Nya, dan bukan pula sekedar mengenal Asma' dan SifatNya. Namun, tauhid adalah pemurnian ibadah kepada Allah. Maksudnya adalah menghambakan diri hanya kepada Allah secara murni dan konsekuen dengan mentaati segala perintah-Nya dan menjauhi segala larangan-Nya, dengan penuh rasa rendah diri, cinta, harap dan takut kepada-Nya (Muhammad Bin Abdul Wahab: 2-3). Hakekat dan inti tauhid adalah agar manusia memandang bahwa semua perkara berasal dari Allah SWT, dan pandangan ini membuatnya tidak menoleh kepada selain Allah SWT tanpa sebab atau perantara. Seseorang melihat yang baik dan buruk, yang berguna dan yang berbahaya dan semisalnya, semuanya berasal dari Allah SWT. Seseorang menyembah-Nya dengan ibadah yang mengesakan-Nya dengan ibadah itu dan tidak menyembah kepada yang lain (Muhammad bin Abdullah At Tuwaijry: 3).

Konsep tauhid yang diajarkan di PAUD Ababil School House ini pada umumnya merupakan pemahaman yang menunjukkan bahwa Allah hanya satu dan merupakan Tuhan Yang Maha Esa. Sehingga konsep pembelajaran tauhid yang diajarkan di PAUD ini merupakan pembiasaanpembiasaan ibadah yang dapat mendekatkan diri kepada-Nya, seperti sholat, do'a harian, haditshadits, surat pendek, dan kegiatan ikhsan lainnya. Namun, pembelajaran tauhid yang diberikan kepada anak didik di PAUD ini tidak hanya sebatas praktek ibadah, akan tetapi mereka juga diberikan pemahaman mana perbuatan yang baik dan mana perbuatan yang tidak boleh dilakukan. Seperti, sebelum anak melaksanakan sholat Dhuha, maka guru menanyakan manfaat sholat Dhuha kepada anak-anak agar mereka tidak hanya mengerjakan ibadah, tetapi mengerti makna dan manfaat ibadah itu sendiri.

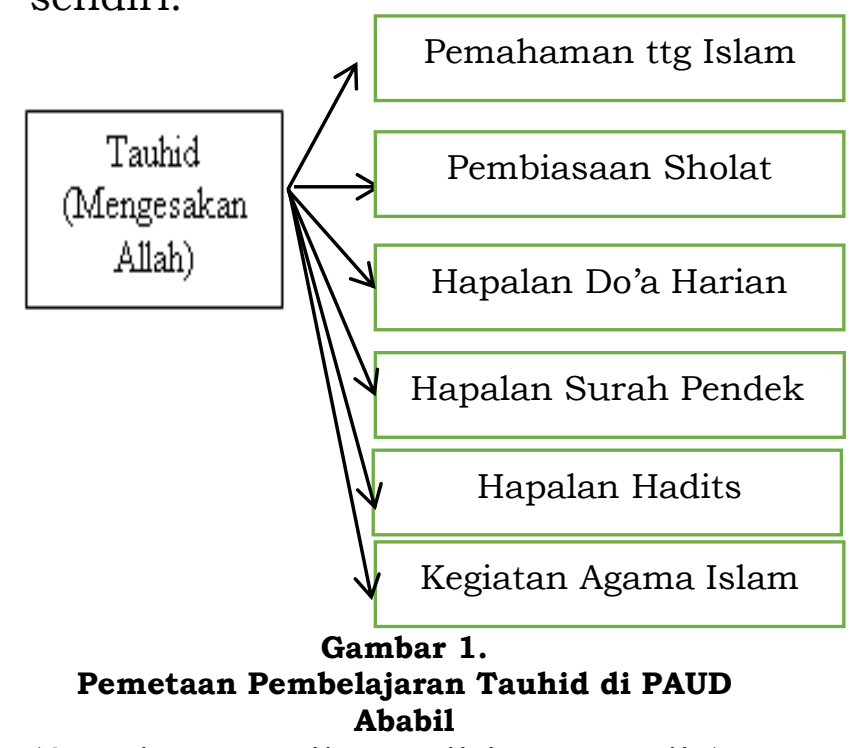

(Sumber: Hasil Penelitian Penulis) 
Konsep pembelajaran berbasis tauhid ini diterapkan di PAUD Ababil dengan harapan ketika anak didik sudah memasuki Sekolah Dasar (SD), mereka sudah banyak hapal do'a-do'a dan praktek ibadah lainnya. Sehingga mereka sudah terbiasa untuk mengenal agama Islam dan mendekatkan diri kepada Allah SWT. Karena jika tidak dibiasakan dari kecil, maka ketika sudah dewasa biasanya mereka sudah susah belajar dan memiliki pengetahuan tentang agama Islam yang minim. Selain praktek ibadah yang diajarkan, anak-anak juga diberikan pengetahuan Islam yang mendasar.

Pembelajaran tauhid di PAUD Ababil ini tidak hanya sebatas pengetahuan saja yang diajarkan kepada anak-anak, namun lebih mendalam dan langsung diaplikasikan oleh anak-anak dalam kehidupan sehari-hari. Penulis mengamati pergaulan bebas yang banyak terjadi di Kota Pangkalpinang ini salah satunya disebabkan karena kurangnya penanaman nilai tauhid sejak dini, sehingga mereka melakukan segala sesuatu melebihi batasan dan aturan yang sudah ditetapkan oleh
Allah SWT melalui ajaran Nabi Muhammad SAW. Oleh sebab itu, pendidikan tauhid sangat penting diajarkan sejak dini agar anak memiliki bekal untuk kehidupan di akhirat kelak, serta dapat mengurangi permasalahan sosial yang sering terjadi pada kehidupan sehari-hari. Karena di dalam pendidikan tauhid itu sendiri merupakan pedoman bagaimana bisa meraih kesuksesan di dunia dan kebahagian di akhirat.

\section{B. Penerapan Konsep Pendidikan Tauhid Anak Usia Dini}

Implementasi atau penerapan merupakan aktualisasi konsep yang sudah dibangun, dalam hal ini penerapan dari konsep pembelajaran tauhid di PAUD Ababil. Pembelajaran tauhid di PAUD Ababil ini sudah dapat diterapkan kepada anak usia dini dari usia 6 bulan sampai 6 tahun.

Sebelum menerapkan pembelajaran tauhid di kelas, maka diperlukan beberapa persiapan yang dilakukan oleh masing-masing guru di kelas. Biasanya persiapan tersebut mereka buat dalam Rencana Pelaksanaan Pembelajaran Harian (RPPH) (Meilisa Bella: 
Wawancara pada tanggal 29 Agustus 2016, Pukul: $11.10 \quad$ WIB). Berdasarkan dokumentasi dan hasil wawancara yang penulis lakukan dapat diketahui bahwa Rencana Pelaksanaan Pembelajaran Tahunan sudah dibuat oleh pihak Yayasan dan dikembangkan kembali oleh masing-masing guru di kelas dalam bentuk RPPH. Pembelajaran yang lebih diutamakan di PAUD Ababil ini adalah pembelajaran tauhid dan bahasa karena PAUD ini memang berbasis bilingual dan tauhid.

Setiap guru di PAUD Ababil sudah mengetahui kewajiban masing-masing dalam proses pembelajaran. Salah satu kewajiban tersebut adalah menyediakan media pembelajaran dalam proses belajar mengajar di kelas agar pembelajaran tersebut menjadi aktif, efektif, kreatif dan menyenangkan. Seorang guru sebelum mengajar harus mempersiapkan materi yang sesuai pada pembelajaran hari itu. Apabila membutuhkan lagu, maka mereka harus mencari lirik dan musik yang dapat membuat anak antusias dan mudah menerima pembelajaran. Guru PAUD yang baik harus memiliki sikap aktif dan kreatif dalam menyajikan pembelajaran yang menyenangkan. Selain itu, guru harus paham materi yang akan diberikan kepada anak didik sebelum menyampaikannya di dalam kelas.

Sebelum memulai kegiatan belajar-mengajar di kelas, maka dimulai dengan membaca do'a-do'a harian, surah-surah pendek, dan hadits-hadits pendek (Iis Rusriani: Wawancara pada tanggal 01 September 2016, Pukul: 13.15 WIB). Selain itu, anak-anak didik juga diajak menyanyikan lagu asmaul husna dan 20 sifat wajib Allah. Setelah membaca do'a-do'a harian, surah-surah pendek, dan haditshadits pendek, anak didik melakukan sholat Dhuha yang dimulai dengan berwudhu. Sebelum berwudhu, anak-anak diajak melakukan tepuk wudhu yang diikuti dengan nyanyian cara berwudhu yang disertai dengan beberapa kosakata bahasa Inggris tentang tubuhku ciptaan $\mathrm{NN}$ :

Tepuk Wudhu

Baca Bismillah lalu cuci tangan (hand)

Kumur-kumur basuh hidung (nose) Cuci muka (face)

Tangan sampai ke siku (elbow) Kepala (head) dan telinga (ear) Terakhir cuci kaki (leg) Lalu do'a

Gambar 2. Lirik Lagu Tepuk Wudhu 
Selanjutnya guru mengajak anak didik melakukan sholat Dhuha dan kemudian diiringi dengan istighfar, dzikir, dan do'a ampunan kedua orang tua. Meskipun anakanak didik di Preschool A belum mampu melaksanakan sholat Dhuha dengan baik, tetapi mereka selalu dibiasakan untuk menggunakan peralatan sholat saat melaksanakan sholat Dhuha. Hal ini bertujuan untuk mengenalkan dan membiasakan kepada anak didik tentang sholat Dhuha.

Setiap hari anak-anak dibiasakan mengaji dengan media buku Iqra' atau flash card yang berisi huruf-huruf Hija'yah. Setelah itu anak diajak makan yang disertai dengan do'a sebelum dan sesudah makan. Adapun sebelum berdo'a dimulai dengan bahasa Inggris dan do'a tersebut menggunakan tiga bahasa, yakni bahasa Arab, bahasa Inggris, dan bahasa Indonesia. Ketika anak-anak didik pulang juga dibiasakan membaca do'a-do'a dan surah-surah pendek terlebih dahulu. Kegiatan atau pembelajaran tersebut merupakan kegiatan rutin yang dilakukan di PAUD Ababil.

Guru di Kindergarten $B$ tidak pernah menyamaratakankan pembelajaran pada setiap anak didiknya. Semakin mudah anak menerima pembelajaran, maka pengetahuan yang diberikan lebih beragam dan menantang. Oleh karena itu, Guru harus tahu tingkat kemampuan anak sudah sampai mana sehingga materi pembelajaran yang diberikan juga berbeda-beda (Novita Dewi: Wawancara pada tanggal 29 Agustus 2016, Pukul: 13.30 WIB). Pendekatan pembelajaran individual yang sudah dilakukan oleh guru di Kindergarten $B$ ini sudah tepat karena melihat pribadi setiap anak didik yang unik dan memiliki kemampuan yang berbeda-beda. Penulis juga melihat, ketika anak sudah mampu mengerjakan atau memahami suatu pembelajaran, maka dia akan mudah bosan.

Guru dalam menerapkan pembelajaran tauhid memiliki SOP (Standar Operasional Pembelajaran) yang sudah mengatur dari awal mereka masuk dalam lingkungan sekolah sampai mereka keluar. Bahkan, lagu-lagu atau nyanyian yang diberikan kepada anak didik harus memiliki nilai-nilai pendidikan dan mampu mengembangkan berbagai aspek 
perkembangan. Berdasarkan hasil wawancara di atas dan observasi yang penulis lakukan, dapat diketahui bahwa pembelajaran yang menyenangkan dengan berbagai nyanyian dan gerakan membuat anak didik lebih mudah mengingat suatu materi pembelajaran. Bahkan, beberapa hadits dan ayat-ayat pilihan dilafalkan dengan lagu-lagu dan gerakan.

Sebagaimana yang kita ketahui bahwa salah satu prinsip pembelajaran Pendidikan Anak Usia Dini adalah bermain sambil belajar, atau belajar sambil bermain. Melalui bermain anak diajak berekplorasi untuk mengenal lingkungan sekitar, menemukan dan memanfaatkan objek-objek yang dekat dengan anak, sehingga pembelajaran menjadi bermakna bagi anak. Metode pembelajaran tauhid yang dilakukan di Preschool $A$ adalah dengan metode bermain. Meskipun, ada juga metode bercerita, namun anak-anak didik di kelas ini belum mampu mendengarkan dengan baik karena terkait dengan faktor usia dimana anak-anak belum mampu berkonsentrasi dengan baik dan juga memang pada masa-masa ini anakanak memang harus lebih banyak bermain untuk mengembangkan aspek-aspek perkembangan lainnya. Namun, berdasarkan hasil pengamatan penulis, anak-anak di kelas ini sudah mampu melakukan pembelajaran dengan metode bernyanyi, karena bernyanyi membuat pembelajaran menjadi lebih menyenangkan. Metode pembelajaran dengan bermain dan bernyanyi juga diterapkan di kelaskelas lain.

Selain menggunakan metode bermain dan bernyanyi, guru di Kindergarten $A$ juga menggunakan metode pengulangan. Kadang ketika mereka bermain maka guru mengajak mengulang-ngulang hapalan. Kalau sering mendengar dan mengulang-ulang mereka akan hapal. Adapun nyanyian dalam pembelajaran tauhid misalnya Asmaul Husna. Apabila tidak dinyanyikan mereka akan sulit. Dengan nyanyian mereka lebih hapal (Neneng Suryani: Wawancara pada tanggal 01 September 2016, Pukul: 13.30 WIB).

Metode pembelajaran tauhid di Kindergarten $B$ lebih berpusat kepada anak didik. Dalam menentukan metode pembelajaran yang tepat terhadap peserta didik, 
biasanya guru ini melihat bagaimana kondisi mood anak didik pada saat itu. Berdasarkan hasil observasi pembelajaran yang penulis lakukan, penulis pernah mengamati di dalam waktu istirahat, guru Kindergarten $B$ ini melakukan permainan ular tangga, dimana di dalam permainan tersebut ada pembelajaran tauhid yang diberikan. Seperti ketika anak-anak turun melewati gambar ular, biasanya anak-anak disuruh melakukan kegiatan berdasarkan aturan yang tertulis di dalam kotak ular tersebut. Kadang-kadang anak-anak disuruh membaca surah-surah pendek. Semua tergantung dalam peraturan yang ada di dalam permainan ular tangga tersebut yang sudah dibuat oleh guru.

Tentunya, seorang guru atau pendidik yang baik harus memiliki strategi pembelajaran yang baik bagi anak didik agar mereka mudah menerima pembelajaran dan tujuan pembelajaran yang ingin dicapai dapat tercapai dengan baik. Masingmasing guru memiliki strategi yang berbeda-beda tergantung tingkat usia anak didik dan karakteristiknya yang berbeda-beda. Strategi pembelajaran yang dilakukan oleh

guru di Preschool $A$ adalah dengan tetap melakukan pembelajaran dengan rutin, meskipun anak-anak tidak mau belajar dan terus berlari kemana-mana. Yang terpenting dilakukan oleh guru tersebut adalah membaca do'a-do'a dengan suara yang bisa didengarkan oleh peserta didik, melakukan sholat Dhuha meskipun mereka belum hapal bacaannya dan konsentrasi melakukan gerakannya, serta tetap menyanyikan lagu-lagu sederhana. Hal senada juga dilakukan oleh guru di Kindergarten B, yang melakukan strategi pembelajaran dengan pembiasaan. Guru di Kindergarten $B$ berasumsi bahwa setiap anak tidak mau membaca, sehingga seorang guru harus selalu membacakan do'a-do'a atau ayat-ayat di depan anak-anak, sehingga mereka mampu mendengarkan apa yang dibaca oleh Sang Guru. Meskipun anak-anak sedang bermain, namun ketika didengarkan terus maka anak tersebut lebih ingat. Bisa jadi hari ini anak-anak tidak bisa karena bermain lalu besok bisa. Hal ini karena mereka mendengar. Meskipun mereka bermain, ketika dites, biasanya anak-anak didik di Kindergarten $B$ bisa. Akan tetapi, IQ 
setiap anak berbeda-beda. Ada juga anak yang diajak mengaji baris 1-3 masih konsentrasi nah ketika baris ke 4 langsung buyar. Ketika anak sudah mulai tidak fokus maka saya tempatkan di samping guru agar guru bisa fokus memperhatikannya (Novita Dewi: Wawancara pada tanggal 29 Agustus 2016, Pukul: 13.30 WIB). Strategi pembelajaran yang dilakukan oleh guru di Kindergarten $B$ sudah baik. Meskipun anak-anak didik dibiasakan mendengar yang dibaca oleh guru, namun mereka harus di tes juga untuk mengetahui sejauh mana anak mampu menerima dan menguasai materi pembelajaran yang diberikan. Adapun strategi pembelajaran yang dilakukan oleh guru di Preschool $B$ adalah dengan cara mengambil hati peserta didik. Sehingga apabila anak-anak didik sudah menyukai gurunya, maka Sang Guru dengan mudah dapat memberikan pembelajaran kepada peserta didik (Meilisa Bella: Wawancara pada tanggal 29 Agustus 2016, Pukul: $11.10 \quad$ WIB). Berdasarkan hasil wawancara tersebut, maka penulis dapat menyimpulkan bahwa strategi pembelajaran yang dilakukan oleh guru di Preschool $B$ adalah dengan membuat anak didik dekat dan menyukai gurunya. Ketika mereka sudah dekat, maka pembelajaran lebih mudah diterima oleh anak didik karena mereka merasa enjoy. Selain itu, ketika guru melakukan pendekatan personal atau individual, guru mampu mengetahui sejauh mana kemampuan anak didik dalam menguasai materi pembelajaran yang diajarkan.

Selain strategi pembelajaran yang dilakukan oleh guru-guru di PAUD ini dengan pembiasaan dan pendekatan individual, penulis juga melihat pembelajaran di PAUD ini dilakukan dengan pendekatan kontekstual (CTL). Hal ini berdasarkan observasi yang penulis lakukan ketika hujan turun, maka guru mengajak anak-anak membaca do'a hujan turun dan disertai dengan artinya.

Masing-masing guru ketika memberikan materi ketauhidan kepada anak didik berbeda-beda. Cara guru Kindergarten $B$ memberikan materi ketauhidan kepada anak didiknya adalah dengan melihat sejauh mana kemampuan mereka menghapal. Apabila anak didik sudah hapal 
ayat-ayat atau surah-surah yang diberikan, maka berganti kepada ayat-ayat atau surah-surah yang baru. Namun, apabila anak didik belum bisa, maka guru tetap membimbing anak didik untuk membaca surat yang baru namun tetap menekankan pada surat yang lama (Novita Dewi: Wawancara pada tanggal 29 Agustus 2016, Pukul: 13.30 WIB). Jika anak didik sudah hapal dalam waktu singkat, maka materi pembelajaran semakin bertambah, dan jika belum hapal maka anak didik terus mengulangulang hapalan tersebut sampai bisa. Hal yang sama juga dilakukan oleh guru-guru yang ada di tingkatan kelas lain, dimana ketika anak belum mampu menguasai suatu materi pembelajaran, maka anakanak tersebut diajak mengulangngulang materi tersebut, baik di sekolah maupun di rumah dengan bimbingan orang tuanya. Pengulangan yang dilakukan bisa dilakukan secara individu maupun langsung bersama-sama.

Salah satu hal yang juga penting dalam proses pembelajaran tauhid di PAUD Ababil ini adalah memanfaatkan media pembelajaran. Memanfaatkan media pembelajaran

ini dapat membuat pembelajaran menjadi lebih menyenangkan dan mudah diterima oleh anak didik. Guru yang baik harus mampu memanfaatkan media pembelajaran yang ada, baik itu media pembelajaran APE (Alat Permainan Edukatif) atau media pembelajaran lainnya. Berdasarkan hasil wawancara dengan guru di Preschool A dapat diketahui bahwa media pembelajaran yang digunakan berupa APE (Alat Permainan Edukatif), dan media ini ada yang disediakan dari kantor dan ada yang dibuat sendiri oleh guru. Namun, dalam pembelajaran tauhid, guru juga pernah menggunakan media pembelajaran televisi dan DVD untuk menonton film yang menceritakan tentang Nabi. Kadang juga menggunakan laptop, alat musik, dan lain-lain (Meilisa Bella: Wawancara pada tanggal 29 Agustus 2016, Pukul: 11.10 WIB).

Media pembelajaran yang digunakan di PAUD Ababil School House ini tidak hanya berupa produk yang sudah jadi, namun juga produk yang dikreasikan oleh guruguru itu sendiri. Selain itu, lembaga PAUD ini juga memanfaatkan alatalat teknologi untuk menunjang 
proses pembelajaran yang bermakna dan menyenangkan bagi peserta didik.

Untuk pembelajaran tauhid tentunya media pembelajaran yang digunakan adalah buku-buku pedoman yang berdasarkan ajaranajaran Islam agar tidak melenceng kepada ajaran-ajaran yang salah. Biasanya media pembelajaran tauhid berupa Al-Qur'an, dan bukubuku hadits supaya tidak melenceng dari kaidahnya atau tajwidnya. Selain itu juga menggunakan flash card untuk mengajarkan pembelajaran huruf Hija'yah.

Untuk penyediaan media pembelajaran itu sendiri sudah difasilitasi oleh pihak yayasan. Biasanya guru sudah menentukan media pembelajaran yang akan digunakan, kemudian menyampaikan kepada pihak administrasi sekaligus merangkap TU di sekolah ini. Berdasarkan hasil wawancara di atas, maka dapat diketahui bahwa guru diberikan kemudahan dalam menentukan dan menyiapkan media pembelajaran yang dibutuhkan. Tentunya sekolah yang baik adalah sekolah yang tidak hanya memfasilitasi pedidikan bagi peserta didik, namun juga memfasilitasi proses pembelajaran yang diinginkan oleh guru, termasuk dalam penyediaan media pembelajaran. Penulis juga memperhatikan bahwa media pembelajaran yang digunakan di PAUD Ababil School House ini bervariasi, ada yang menggunakan barang yang sudah jadi, ada yang menggunakan barang bekas, dan ada juga yang memanfaatkan teknologi, seperti: handphone, tape, sound system, DVD dan proyektor.

Secara

keseluruhan penerapan atau implementasi konsep pembelajaran tauhid di PAUD Ababil dirangkum dalam tabel berikut:

Tabel 1.

Implementasi Pembelajaran Tauhid di PAUD Ababil

\begin{tabular}{|c|c|c|c|c|}
\hline $\begin{array}{c}\text { Pembelaj } \\
\text { aran }\end{array}$ & $P S A$ & $P S B$ & $K G A$ & $K G B$ \\
\hline Materi & $\begin{array}{l}\text { - Sholat } \\
\text { Dhuha } \\
\text { - Huruf } \\
\text { Hija'yah } \\
\text { - Do'a } \\
\text { harian. } \\
\text { - Banyak } \\
\text { menge } \\
\text { mbangk } \\
\text { an } \\
\text { aspek } \\
\text { fisik- } \\
\text { motorik. }\end{array}$ & $\begin{array}{l}\text { - Sholat } \\
\text { Dhuha } \\
\text { - Iqra' } \\
\text { - Do'a } \\
\text { harian }\end{array}$ & $\begin{array}{l}\text { - Sholat } \\
\text { Dhuha } \\
\text { - Iqra' } \\
\text { - Do'a } \\
\text { harian } \\
\text { - Hadits } \\
\text { - Surah } \\
\text { Pende } \\
\text { k } \\
\text { - Ilmu } \\
\text { Agama }\end{array}$ & $\begin{array}{l}\text { - Sholat } \\
\text { Dhuha } \\
\text { - Iqra' } \\
\text { - Do'a } \\
\text { harian } \\
\text { - Hadits } \\
\text { - Surah } \\
\text { Pendek } \\
\text { - Ilmu } \\
\text { Agama }\end{array}$ \\
\hline $\begin{array}{l}\text { Penguasa } \\
\text { an Materi }\end{array}$ & $\begin{array}{c}\text { - Belum } \\
\text { fokus. }\end{array}$ & $\begin{array}{l}\text { - Kadan } \\
\text { g- } \\
\text { kadan } \\
\text { g bisa } \\
\text { fokus. }\end{array}$ & $\begin{array}{l}- \text { Belum } \\
\text { bisa } \\
\text { fokus } \\
\text { denga } \\
\text { n baik. }\end{array}$ & $\begin{array}{c}\text { - Sudah } \\
\text { bisa } \\
\text { fokus. }\end{array}$ \\
\hline Metode & $\begin{array}{l}\text { - Bernyan } \\
\text { yi. }\end{array}$ & $\begin{array}{c}\text { - Berny } \\
\text { anyi. }\end{array}$ & $\begin{array}{c}\text { - Berny } \\
\text { anyi. }\end{array}$ & $\begin{array}{l}\text { - Bernyan } \\
\text { yi. }\end{array}$ \\
\hline
\end{tabular}




\begin{tabular}{|c|c|c|c|c|}
\hline & $\begin{array}{l}\text { - Ketelad } \\
\text { anan. } \\
\text { - Demons } \\
\text { trasi. } \\
\text { - Bermain } \\
\text { - Karya } \\
\text { wisata. }\end{array}$ & $\begin{array}{l}\text { - Ketela } \\
\text { danan. } \\
\text { - Demo } \\
\text { nstrasi } \\
\text { - Berma } \\
\text { in. } \\
\text { - Karya } \\
\text { wisata } \\
\text {. } \\
\text { - Bercer } \\
\text { ita. } \\
\text { - Tanya } \\
\text { jawab. }\end{array}$ & $\begin{array}{l}\text { - Ketela } \\
\text { danan. } \\
\text { - Demo } \\
\text { nstrasi } \\
\text { - Berma } \\
\text { in. } \\
\text { - Karya } \\
\text { wisata } \\
\text { - Bercer } \\
\text { ita. } \\
\text { - Tanya } \\
\text { jawab. }\end{array}$ & $\begin{array}{l}\text { - Ketelad } \\
\text { anan. } \\
\text { - Demons } \\
\text { trasi. } \\
\text { - Bermain } \\
\text { - Karya } \\
\text { wisata. } \\
\text { - Bercerit } \\
\text { a. } \\
\text { - Tanya } \\
\text { jawab. }\end{array}$ \\
\hline Strategi & $\begin{array}{l}\text { - Pembias } \\
\text { aan. } \\
\text { - Pengula } \\
\text { ngan. }\end{array}$ & $\begin{array}{l}\text { - Memb } \\
\text { uat } \\
\text { anak } \\
\text { didik } \\
\text { senan } \\
\text { g. } \\
\text { - Pembi } \\
\text { asaan. } \\
\text { - Pengul } \\
\text { angan }\end{array}$ & $\begin{array}{c}\text { - Pembi } \\
\text { asaan. } \\
\text { - Pengul } \\
\text { angan }\end{array}$ & $\begin{array}{l}\text { - Melihat } \\
\text { mood } \\
\text { anak } \\
\text { didik. } \\
\text { - Membe } \\
\text { dakan } \\
\text { tingkat } \\
\text { kemam } \\
\text { puan } \\
\text { anak } \\
\text { didik. } \\
\text { - Pembias } \\
\text { aan. } \\
\text { - Pengula } \\
\text { ngan. } \\
\text { - Menget } \\
\text { es } \\
\text { ulang. }\end{array}$ \\
\hline Media & $\begin{array}{l}\text { - Buku } \\
\text { ajar. } \\
\text { - Tape. } \\
\text { - APE. } \\
\text { - Alat } \\
\text { sholat. } \\
\text { - Disesuai } \\
\text { kan } \\
\text { dengan } \\
\text { tema } \\
\text { pembel } \\
\text { ajaran. }\end{array}$ & $\begin{array}{l}\text { - Buku } \\
\text { ajar. } \\
\text { - Tape. } \\
\text { - APE. } \\
\text { - Alat } \\
\text { sholat. } \\
\text { - Disesu } \\
\text { aikan } \\
\text { denga } \\
\text { n } \\
\text { tema. }\end{array}$ & $\begin{array}{l}\text { - Buku } \\
\text { ajar. } \\
\text { - Tape. } \\
\text { - APE. } \\
\text { - Alat } \\
\text { sholat. } \\
\text { - Disesu } \\
\text { aikan } \\
\text { denga } \\
\text { n } \\
\text { tema. }\end{array}$ & $\begin{array}{l}\text { - Buku } \\
\text { ajar. } \\
\text { - Tape. } \\
\text { - APE. } \\
\text { - Alat } \\
\text { sholat. } \\
\text { - Disesuai } \\
\text { kan } \\
\text { dengan } \\
\text { tema } \\
\text { pembel } \\
\text { ajaran. }\end{array}$ \\
\hline $\begin{array}{l}\text { Intervens } \\
\text { i Guru }\end{array}$ & $\begin{array}{l}\text { - Guru } \\
\text { banyak } \\
\text { berpera } \\
\mathrm{n} .\end{array}$ & $\begin{array}{l}\text { - Masih } \\
\text { ada } \\
\text { interv } \\
\text { ensi } \\
\text { guru. }\end{array}$ & $\begin{array}{l}\text { - Guru } \\
\text { jadi } \\
\text { fasilita } \\
\text { tor. }\end{array}$ & $\begin{array}{l}\text { - Guru } \\
\text { jadi } \\
\text { fasilitato } \\
\text { r. }\end{array}$ \\
\hline
\end{tabular}

Setelah menerapkan konsep pembelajaran berbasis tauhid, baik program pembelajaran harian maupun pembelajaran khusus, maka guru juga melakukan program evaluasi pembelajaran untuk mengetahui perkembangan anak didik setelah menerapkan konsep pembelajaran tersebut. Evaluasi atau penilaian pembelajaran di PAUD ini ada penilaian observasi, portofolio dan raport.

Teknik penilaian yang dilakukan oleh masing-masing guru berbeda-beda. Penulis melihat, karena setiap kelas ada dua guru yang memberikan pembelajaran, maka penilaian juga dibagi dua. Dimana setiap guru sudah memiliki tanggung jawab dalam menilai perkembangan masing-masing anak yang diampunya. Namun, penilaian yang dilakukan di Preschool $A$ tidak bisa dilakukan setiap hari, hal ini dikarenakan setiap hari mood anakanak berbeda-beda, sehingga strategi penilaian yang dilakukan oleh guru di Preschool $A$ ini dengan melihat perkembangan anak setiap hari. Penilaian yang dilakukan di Kindergarten $A$ dan Kindergarten $B$ sudah dapat dinilai dengan baik. Mereka sudah bisa dites, baik hapalan do'a-do'anya, maupun vocabulary dan conversation yang diberikan. Penilaian yang dilakukan 
guru dilakukan seminggu sekali.

Secara keseluruhan keberhasilan

program pembelajaran yang

diberikan di Kindergarten $B$ dapat

dilihat pada minggu ke 4 .

Tentunya penilaian yang dilakukan kepada anak didik dilakukan secara individual untuk mengetahui sejauh mana kemampuan anak didik dalam menerima pembelajaran tauhid di PAUD Ababil ini. Teknik dan strategi penilaian yang dilakukan oleh guru dapat dilakukan sebagai berikut:

"Kita memperhatikan anakanak satu persatu. Karena anak sudah bersama kita dari pagi sampai siang maka ada niat untuk melihat kemampuan mereka satu persatu. Karena kelihatan kalau anak yang disuruh do'a dan dia berdo'a itu ketahuan kalau dia tahu, atau anakanak asal ikut pada akhirnya dia tahu. Tapi anak yang sering bermain itu dipertanyakan dan dites untuk mengetahui kemampuannya. Misalnya, ketika kita suruh membaca An-Nas ada yang tidak baca maka kita suruh baca sendiri untuk mengetahui sampai mana kemampuannya. Tes ini juga dilakukan secara berkesinambungan untuk melihat apakah ada perubahan atau tidak. Apalagi anak yang bersuara besar kelihatan dia hapal atau tidak, ada yang bersuara besar tapi hanya ikut-ikutan dan tidak jelas apa yang dia omongkan padahal hanya berteriak yang penting suaranya besar. Pas di tes tidak hapal. Kita sebagai guru jangan sekedar membaca dan mengajak anak membaca ayat atau do'a bersama-sama tapi kita harus mendengar mereka satu-persatu." (Novita Dewi: Wawancara pada tanggal 29 Agustus 2016, Pukul: 13.30 WIB)

Pengetesan yang dilakukan oleh guru secara individual ini sangat penting untuk dilakukan sebagai bahan evaluasi pembelajaran untuk melihat kekurangan apa yang ada pada anak didikdan bagaimana cara mengatasi permasalahan pembelajaran yang terjadi.

Berhubung PAUD Ababil tauhid, maka penilaian yang pertama dilakukan adalah penilaian perkembangan tauhid, kemudian penilaian perkembangan sosialemosional dan kemandirian, perkembangan bahasa, dan dilanjutkan dengan penilaian perkembangan anak lainnya. Namun, di setiap penilaian aspek perkembangan, ada juga indikatorindikator pembelajaran yang ingin dicapai anak didik.

Berdasarkan hasil wawancara dan observasi yang penulis lakukan 
dapat disimpulkan bahwa pembelajaran berbasis tauhid di PAUD Ababil ini dinilai secara individual dan dilakukan pengetesan kepada setiap anak didik untuk mengetahui sejauh mana perkembangan pembelajarannya. Namun, setiap anak didik memiliki tingkat pencapaian pembelajaran yang berbeda. Adapaun anak-anak yang belajar di PAUD Ababil ini secara berkesinambungan dan bertahap tingkatan kelasnya, maka lebih mudah menerima pembelajaran dibandingkan anakanak yang baru masuk di kelas baru. Namun, secara keseluruhan guruguru tidak mengalami hambatan dalam memberikan pembelajaran kepada anak didik karena mereka memiliki daya tangkap yang cepat dalam memahami pembelajaran. Meskipun ada, biasanya itu anak yang berkebutuhan khusus (ABK). Walaupun demikian, ketika anakanak berkebutuhan khusus tersebut diberikan treatment-treatment khusus yang dilakukan oleh pihak yayasan, maka anak tersebut juga mudah menerima pembelajaran.

Meskipun tingkat kemampuan pembelajaran anak didik dalam mempelajari pembelajaran berbasis

tauhid di PAUD ini berbeda-beda, namun rata-rata mereka sudah mampu mengikuti materi pembelajaran selama 1-2 bulan. Hal ini sebagaimana hasil wawancara yang penulis lakukan dengan guru Kindergarten $A$ berikut ini:

"Anak-anak di TK A ada yang dari Preschool ada yang baru. Untuk anak ada yang cepat mengikuti pelajaran karena dari rumah sudah dibiasakan, misalnya ketika anak sudah sering didengarkan Al-Fatihah dari rumah agak mudah menangkap materi tentang surah ini. Namun, anak yang jarang didengarkan ayat ini agak lama mempelajarinya. Anak-anak di TK A biasanya sudah bisa mengikuti materi selama 1-2 bulan. Rata-rata anak bisa. Kecuali anak yang tidak bisa karena ada kelainan, seperti berkebutuhan khusus." (Neneng Suryani: Wawancara pada tanggal 01 September 2016, Pukul: 13.30 WIB)

Setelah pendidik melakukan penilaian harian dan bulanan, selanjutnya penilaian tersebut mereka rangkum dan tulis dalam buku raport yang memuat perkembangan anak didik selama satu semester. Penilaian yang diberikan kepada anak didik mencakup: 
- Achieve (A): anak mampu melakukannya tanpa bantuan sekali.

- Good (G): anak mampu melakukannya dengan sedikit bantuan.

- Enough (E): anak sedikit mampu melakukannya dan banyak bantuan.

- Need Praktice (NP): Anak belum mampu melakukannya dan masih membutuhkan banyak bimbingan baik di sekolah maupun di rumah.

Raport yang ditulis mencakup penilaian perkembangan anak didik yang dimulai dengan perkembangan anak didik di bidang tauhid, kemudian perkembangan sosial emosional dan kemandirian, perkembangan bahasa, perkembangan kognitif, perkembangan fisik motorik, dan perkembangan seni. Secara keseluruhan, peneliti melihat aspek yang ditonjolkan di PAUD Ababil ini adalah aspek perkembangan tauhid kemudian perkembangan sosial emosional dan kemandirian, serta perkembangan bahasa. Untuk perkembangan kognitif tidak begitu diutamakan karena memang masa anak-anak adalah masa bermain, bukan masa belajar sebagaimana anak-anak di tingkatan Sekolah Dasar, SMP dan SMA. Meskipun demikian, pembelajaran di PAUD ini juga menstimulus perkembangan anak didik yang lainnya.

Tentunya dalam proses pembelajaran berbasis tauhid di PAUD Ababil School House ini mengalami kendala. Kendala yang dialami guru dalam proses pembelajaran ini pun beragam. Guru di Preschool A mengalami kendala bahwa anak didik belum bisa berbicara dan memiliki sosial emosional yang kurang. Berdasarkan hasil observasi penulis pada pembelajaran di kelas Preschool A ini, penulis melihat masih banyak anak didik yang belum bisa berbicara dan menyampaikan sesuatu dengan tangisan. Selain itu, ada juga anak yang sudah bisa berbicara, namun sering berbuat kasar dengan teman sepermainannya. Meskipun demikian guru di Preschool A ini selalu menanamkan nilai-nilai tauhid dalam proses pembelajaran yang dilakukan secara berkesinambungan. Menurut guru di Preschool A, "Walaupun mereka lari-lari dan belum bisa berbicara 
yang jelas kita tetap baca surahsurah dan nyanyi-nyanyi." (Iis Rusriani: Wawancara pada tanggal 01 September 2016, Pukul: 13.15 WIB)

Adapun kendala yang dialami oleh guru di Preschool $B$ adalah anak-anak belum mampu menguasai dan membaca huruf Hija'yah dengan benar. Solusi yang dilakukan oleh guru di Preschool B dalam menghadapi permasalahan tersebut adalah dengan mengajarkan anak didik dengan memanfaatkan media pembelajaran flash card yang berisi huruf-huruf Hija'yah. Kendala lain juga dialami oleh guru di Kindergarten A, dimana anak-anak belum bisa duduk, fokus, diam serta masih senang berjalanjalan ketika sedang dalam proses pembelajaran.

Pengalaman pembelajaran serupa juga terjadi pada anak-anak didik di Kindergarten B. Namun, solusi yang diberikan adalah dengan memberikan reward berupa stiker atau nanyian kepada anak didik yang fokus dan melaksanakan perintah guru.

Berdasarkan hasil wawancara dan observasi yang penulis lakukan di PAUD Ababil ini, maka dapat disimpulkan bahwa kendalakendala yang dialami oleh pendidik atau guru dalam proses pembelajaran berbeda-beda dan memiliki solusi yang berbeda. Kelas Preschool A yang mengalami kendala pembelajaran pada anak-anak yang belum bisa berbicara dan memiliki sosial emosional yang belum baik diberikan solusi dengan selalu membaca dan mendengarkan kepada mereka tentang materi pembelajaran yang diajarkan. Untuk kelas Preschool $B$ yang memiliki masalah anak-anak belum bisa membaca huruf Hija'yah dengan benar, maka diberikan solusi dengan memanfaatkan flash card yang berisi huruf-huruf Hija'yah. Adapun untuk kelas Kindergarten $A$ dan Kindergarten $B$ yang memiliki kendala anak-anak kurang fokus dan tidak mau diam dalam proses pembelajaran, maka diberikan reward untuk menambah antusis mereka untuk belajar.

\section{Dampak}

Implementasi Pembelajaran Tauhid terhadap Anak Didik

Setelah menerapkan pembelajaran berbasis bilingual dan tauhid, maka setiap anak didik 
tentunya memiliki dampak atau implikasi dalam kehidupannya sehari-hari. Berdasarkan hasil observasi dan wawancara yang penulis lakukan, maka dampak implementasi atau penerapan pembelajaran tauhid ini dapat dilihat dari perubahan perilaku anak didik, baik di sekolah maupun di rumah.

Tabel 2.

Dampak Implementasi Pembelajaran Tauhid pada Peserta Didik

\begin{tabular}{|c|l|l|}
\hline No & Dampak di Sekolah & \multicolumn{1}{|c|}{$\begin{array}{c}\text { Dampak di } \\
\text { Rumah }\end{array}$} \\
\hline 1 & $\begin{array}{l}\text { Mampu } \\
\text { membacakan ayat- } \\
\text { ayat, surah-surah, } \\
\text { hadits-hadits dan } \\
\text { do'a-do'a saat } \\
\text { wisuda. }\end{array}$ & $\begin{array}{l}\text { Mengajak } \\
\text { kakaknya } \\
\text { sholat. }\end{array}$ \\
\hline 2 & $\begin{array}{l}\text { Ketika ada teman } \\
\text { yang sedang marah- } \\
\text { marah, mereka } \\
\text { langsung } \\
\text { menyebutkan hadits } \\
\text { dan membuat } \\
\text { temannya berhenti } \\
\text { marah-marah. }\end{array}$ & $\begin{array}{l}\text { Memiliki pribadi } \\
\text { yang lebih } \\
\text { religius dan } \\
\text { memiliki budi } \\
\text { pekerti yang } \\
\text { baik. }\end{array}$ \\
\hline 3 & $\begin{array}{l}\text { Ketika mempelajari } \\
\text { hadits jangan } \\
\text { minum sambil } \\
\text { berdiri, maka } \\
\text { mereka } \\
\text { membiasakan } \\
\text { untuk makan dan } \\
\text { minum duduk. }\end{array}$ & $\begin{array}{l}\text { Mengajarkan } \\
\text { orang tuanya } \\
\text { untuk makan } \\
\text { dan minum } \\
\text { tidak berdiri. }\end{array}$ \\
\hline 4 & $\begin{array}{l}\text { Mengetahui baik } \\
\text { buruk dalam Islam. }\end{array}$ & $\begin{array}{l}\text { Hapal hadits- } \\
\text { hadits, do'a-do'a } \\
\text { harian, dan } \\
\text { surah pendek. }\end{array}$ \\
\hline
\end{tabular}

Agar pembelajaran tauhid berjalan dengan baik, maka terdapat program khusus dalam meningkatkan ketauhidan pada seluruh komponen yang ada di PAUD Ababil School House. Miss. Yaya mengungkapkan bahwa "Biasanya setiap hari Jum'at minggu kedua atau ketiga ada sholat Dhuha berjama'ah. Kalau anak didikotomatis sholat Dhuha. Kalau pengajian belum ada palingan teman-teman itu kalau nanya soal agama-agama itu nanyanya ke saya. Biasanya kalau tahun kemarin setiap hari Jum'at guru-guru di tes Asmaul Husna, sehingga kita harus memiliki peningkatan. Saya ulangi lagi jika makhrojul hurufnya yang tidak benar maka diluruskan kembali. Kemudian teman-teman saya tes juga mengaji." (Nurfitriansyah: Wawancara pada tanggal 30 Agustus 2016, Pukul: 13.15 WIB)

Tentunya, beberapa program khusus di atas sangat penting dilakukan oleh pendidik yang ada di lembaga PAUD ini. Miss. Ria juga menekankan kepada semua guru sebelum mengajarkan ilmu tauhid kepada anak-anak didik, maka harus tahu terlebih dahulu materi yang ingin disampaikan, sebagaimana yang diungkapkannya sebagai berikut:

"Semua guru harus tahu sebelum mengajarkan kepada anak-anak. Untuk menambah 
ilmu ketauhidan pada guru maka dicarikan guru yang berkompeten dalam bidang ini dimana di hari Sabtu ada guru yang mengajar ngaji dan sebagainya. Ini baru wacana karena gurunya sedang cuti mengajar." (Riana Dewi: Wawancara pada tanggal 29 Agustus 2016, Pukul: 10.45 WIB)

Meskipun masih wacana, namun pihak sekolah sangat menekankan kepada pendidik untuk mengajar ilmu tauhid berdasarkan tuntunan ajaran Islam yang benar dengan belajar dari guru yang berkompeten di bidangnya, sehingga apa yang diajarkan pendidik kepada anak didik tidak melenceng dari ajaran-ajaran Islam.

\section{IV.KESIMPULAN}

Konsep pembelajaran tauhid yang diajarkan di PAUD Ababil merupakan pemahaman yang menunjukkan bahwa Allah hanya satu. Materi tauhid yang diajarkan di PAUD ini adalah sholat, do'a harian, hadits-hadits, surat pendek, dan kegiatan ikhsan lainnya. Pembelajaran tauhid sudah diajarkan dari usia 6 bulan sampai 6 tahun. Penyampaian materi pembelajaran tauhid yang dilakukan guru tergantung tingkatan umur dan kelasnya. Ouput pembelajaran tauhid adalah anak didik mampu melakukan praktek ibadah berdasarkan panduan ajaran Islam dalam kehidupan sehari-hari yang dapat menumbuh-kembangkan karakter religius dalam diri mereka dan memiliki akhlak yang mulia.

\section{DAFTAR PUSTAKA}

Hasbi, M., "Konsep Tauhid sebagai Problematika Pendidikan Agama bagi Siswa Madrasah", Jurnal Pemikran Alternatif Kependidikan, Insania, Vol. 14, No. 2, Mei-Agustus 2009.

Muhammad Bin Abdul Wahab, Kitab Tauhid, terj., www.islamhouse.com, diakses tanggal 12 Desember 2016.

Muhammad bin Abdullah At Tuwaijry, Tauhid, Keutamaan dan Macam-Macamnya, terj., www.islamhouse.com, diakses tanggal 12 Desember 2016.

Sugiyono, 2016, Metode Penelitian Pendidikan: Pendekatan Kuantitatif, Kualitatif, dan $R \&$ D, Bandung: Alfabeta, 2016.

Suyadi dan Maulidya Ulfah, 2012, Konsep Dasar PAUD, Bandung: PT Remaja Rosdakarya. 